\title{
PENGARUH PENAMBAHAN CHORIONIC GONADOTROPHIN PADA MEDIUM MATURASI TERHADAP KEMAMPUAN MATURASI, FERTILISASI, DAN PERKEMBANGAN EMBRIO SECARA IN VITRO KAMBING PERANAKAN ETTAWA
}

\section{THE EFFECT OF CHORIONIC GONADOTROPHIN ADDITION INTO MATURATION MEDIUM ON THE ABILITY OF OOCYTES MATURATION, FERTILIZATION, AND EMBRYO DEVELOPMENT IN VITRO ON THE ETTAWA CROSSBRED}

\author{
Nurvina Septi Adifa, Pudji Astuti, dan Diah Tri Widayati* \\ Fakultas Peternakan, Universitas Gadjah Mada, Jl. Fauna No.3, Bulaksumur, Yogyakarta, 55281
}

\section{INTISARI}

Penelitian ini dilakukan untuk mengetahui pengaruh penambahan chorionic gonadotrophin dalam medium maturasi terhadap kemampuan maturasi oosit, fertilisasi, dan perkembangan embrio kambing Peranakan Ettawa (PE) secara in vitro. Oosit dibagi menjadi 3 kelompok, yaitu kelompok I, medium maturasi tanpa penambahan chorionic gonadotrophin (0); kelompok II, medium maturasi dengan penambahan chorionic gonadotrophin $10 \mu \mathrm{l} / 10 \mathrm{ml}$; dan kelompok III, medium maturasi dengan penambahan chorionic gonadotrophin $20 \mu \mathrm{l} / 10 \mathrm{ml}$. Oosit yang diperoleh, dipindahkan pada media maturasi $50 \mu$ l, kemudian ditutup dengan mineral oil. Oosit dimaturasi dalam inkubator $\mathrm{CO}_{2}$ pada suhu $39^{\circ} \mathrm{C}$, kadar $\mathrm{CO}_{2} 5 \%$, kelembaban 95\% selama 24 jam. Oosit yang matur diinseminasi dengan spermatozoa kapasitasi dengan konsentrasi $12,5 \times 10^{6} / \mathrm{ml}$. Proses fertilisasi dilakukan dalam inkubator $\mathrm{CO}_{2}$ pada suhu $39^{\circ} \mathrm{C}$, kadar $\mathrm{CO}_{2}$ 5\%, kelembaban 95\% selama 5 jam. Oosit dipindahkan ke dalam tetes G-1 $50 \mu$ l, kemudian dimasukkan dalam inkubator $\mathrm{CO}_{2}$ pada suhu $39^{\circ} \mathrm{C}$, kadar $\mathrm{CO}_{2} 5 \%$, kelembaban 95\%. Perkembangan embrio diamati setiap 24 jam. Medium diganti setiap 48 jam. Medium G-2 digunakan hari kedua setelah kultur. Variabel yang diamati meliputi persentase oosit yang matur, angka fertilisasi, dan angka pembelahan. Data dianalisis dengan chi-square, menggunakan program SPSS 15,0. Hasil menunjukan bahwa persentase oosit yang matur dan angka fertilisasi tidak berbeda nyata secara berturut-turut yaitu 78,0\%,72,8\%,75,0\% dan 76,6\%,74,5\%,77,8\%. Tetapi angka pembelahan terdapat perbedaan yang nyata $(\mathrm{P} \leq 0,05)$ secara berturut-turut yaitu $40,8 \%, 11,4 \%$, dan $12,2 \%$. Berdasarkan hasil penelitian dapat disimpulkan bahwa penambahan chorionic gonadotrophin dalam medium maturasi tidak meningkatkan angka maturasi, fertilisasi, dan pembelahan embrio kambing PE in vitro. Angka maturasi, fertilisasi, dan pembelahan embrio yang paling baik adalah menggunakan medium tanpa penambahan chorionic gonadotrophin.

(Kata kunci: Oosit kambing, Chorionic gonadotrophin, Maturasi in vitro, Fertilisasi in vitro, Perkembangan embrio in vitro)

\section{ABSTRACT}

This research was conducted to investigate the effect of chorionic gonadotrophin addition into maturation medium on oocyte maturation, fertilization, and embryo development in vitro of Ettawa crossbred. Oocytes were divided into 3 groups, group I: maturation medium without addition of chorionic gonadotrophin (0), group II: $10 \mu \mathrm{l} / 10$ $\mathrm{ml}$ chorionic gonadotrophin was added into maturation medium (1), group III: $20 \mu \mathrm{l} / 10 \mathrm{ml}$ chorionic gonadotrophin was added into maturation medium (2). Oocytes were transferred into $50 \mu l$ maturation medium, then covered by mineral oil. Oocyte was incubated at $39^{\circ} \mathrm{C}, 5 \% \mathrm{CO}_{2}, 95 \%$ humidity for 24 hours for maturation. Matured oocytes were inseminated with frozen semen-thawed concentration $12.5 \times 10^{6} / \mathrm{ml}$. Process of fertilization were carried out on incubator $39^{\circ} \mathrm{C}, 5 \% \mathrm{CO}_{2}, 95 \%$ humidity for 5 hours. The fertilized oocytes were transferred into $50 \mu \mathrm{l}$ drop $G-1$, then incubated at $39^{\circ} \mathrm{C}, 5 \% \mathrm{CO}_{2}$, 95\% humidity. Embryo development was monitored every 24 hours. Culture medium was changed every 48 hours. G-2 medium used second day after culture. The variables measured involved oocyte maturation, fertilization, and in vitro cleavage rate. The data were analyzed by chi-square, using SPSS 15.0 program. The result showed no significant difference on the percentage of mature oocytes and fertilization rate were $78.0 \%$, $72.8 \%, 75.0 \%$ and $76.6 \%, 74.5 \%, 77.8 \%$ respectively. But cleavage rate showed significant difference $(P \leq 0.05)$ with the values of $40.8 \%, 11.4 \%$, and $12.2 \%$ respectively. Based on the result it could be concluded that chorionic gonadotrophin addition into maturation medium had not increased ettawa crossbred oocytes maturation, fertilization, and in vitro cleavage rate. The best maturation, fertilization, and in vitro cleavage rate were found using maturation medium without any addition of chorionic gonadotrophin.

(Key words: Does oocyte, Chorionic gonadotrophin, In vitro maturation, In vitro fertilization, In vitro embryo development)

\footnotetext{
* Korespondensi (corresponding author):

Telp.+62 811255 673, E-mail: widayati@ugm.ac.id
} 


\section{Pendahuluan}

Transfer embrio merupakan teknik untuk mempercepat proses reproduksi dengan mutu genetik yang unggul. Embrio secara konvensional yang didapatkan secara in vivo memerlukan biaya mahal dan respon untuk super ovulasi bervariasi (Situmorang dan Triwulaningsih, 2004). Alternatifnya adalah memproduksi embrio secara in vitro. Fertilisasi in vitro sebagian dari teknologi transfer embrio, merupakan teknologi baru untuk produksi embrio secara masal dan murah (Putro, 1993).

Pesatnya perkembangan teknologi ini didorong oleh kebutuhan embrio yang berkualitas unggul dan biaya murah karena memanfaatkan limbah pemotongan dari rumah potong hewan, sedangkan spermatozoa berasal dari pejantan unggul. Prosedur fertilisasi in vitro meliputi: pengambilan oosit dari ovarium, maturasi oosit in vitro, kapasitasi sperma in vitro, fertilisasi in vitro, dan kultur oosit yang sudah difertilisasi.

Kemampuan maturasi oosit secara in vitro lebih rendah daripada secara in vivo. Maturasi oosit secara in vitro dapat ditingkatkan dengan penambahan hormon gonadotropin dalam media maturasi (Choi et al., 2001). Salah satu hormon gonadotropin adalah chorionic gonadotrophin (LH-like), merupakan hormon protein yang dihasilkan dari tropoblas fetus. Namun, pengaruh penambahan hormon chorionic gonadotrophin pada medium maturasi pada kambing PE in vitro belum diketahui, maka perlu dilakukan penelitian untuk mengetahui pengaruh penambahan hormon chorionic gonadotrophin pada medium maturasi kambing Peranakan Ettawa (PE) in vitro.

Teknik fertilisasi in vitro kini paling banyak dikembangkan pada ternak sapi. Penelitian tentang produksi embrio in vitro pada kambing baik di tingkat nasional maupun internasional masih sangat rendah. Beberapa hasil penelitian produksi embrio blastosis pada sapi sekitar 30-40\% (Blerkom et al., 1990), domba 36\%, dan kambing $11 \%$ (Boediono et al., 1999).

Hormon berpartisipasi dalam proses reproduksi alami. Partisipasi ini mungkin melalui kerja langsung hormon terhadap suatu aspek khusus reproduksi atau melalui kerja tidak langsung hormon terhadap kelangsungan fisiologis lingkungan internal yang menjamin keberhasilan reproduksi. Chorionic gonadotrophin adalah hormon protein yang dihasilkan oleh tropoblas fetus. Prinsip aksinya adalah LH-like dan menjaga korpus luteum selama kebuntingan (Bearden dan Fuquay, 1997). LH mempunyai fungsi merangsang maturasi folikel, merangsang ovulasi, dan membentuk korpus luteum (Djojosoebagio, 1990) dan fungsi selularnya adalah menaikkan steroidogenesis (William, 1974).
Mekanisme LH mempengaruhi maturasi oosit sapi kemungkinan mengubah distribusi kalsium dalam ooplasma dan gonadotropin dapat meningkatkan glikolisis, disertai dengan meningkatnya oksidasi glukosa mitokondria dalam sel kumulus (Zuelke dan Brackett, 1992; 1993).

Oosit yang diperoleh dari folikel ovarium merupakan oosit yang belum matur, artinya belum mencapai tingkat maturasi sitoplasma yang siap dibuahi atau difertilisasi. Sehingga oosit perlu dimaturasi terlebih dahulu sebelum dilakukan fertilisasi in vitro (Putro, 1993). Oosit matur merupakan produk dari pembelahan meiosis pertama yaitu oosit sekunder dan first polar body (PB I), yang terletak di antara membran vitelina (membran plasma) dan zona pelusida di ruang perivitelin. Jumlah kromosom oosit berubah dari status diploid (2n) ke haploid (n). Pembelahan meiosis pertama sempurna sesaat sebelum ovulasi pada sapi, babi serta domba betina, dan segera setelah ovulasi pada kuda betina (Bearden dan Fuquay, 1997). Maturasi oosit dipengaruhi oleh maturasi nukleus dan kualitas fisiologis dari nukleus, sitoplasma, dan zona pelusida yang transparan (Tanaka, 2001). Beberapa komponen penting pada maturasi nukleus dan sitoplasma yaitu terputusnya membran nukleus yang disebut germinal vesicle break down (GVBD), ekstrusi polar body pertama (PB I), dan ekspansi sel-sel kumulus (Gordon, 1994).

Kapasitasi dan reaksi akrosom merupakan persiapan yang esensial. Proses fertilisasi meliputi penetrasi spermatozoa pada zona pelusida, dengan terkelupas dan hilangnya membran akrosom bagian luar yang bervesikula dan membran plasma pada permukaan zona. Penerobosan melalui zona sebagian disebabkan oleh aksi setempat dari akrosin yang berkaitan dengan membran, tetapi peningkatan motilitas akibat kapasitasi tetap berperan penting dalam fase penetrasi. Langkah ini diikuti perlekatan spermatozoa pada membran plasma (vitelina) sel telur, berhentinya aktivitas flagela, penggabungan kepala spermatozoa ke dalam ooplasma melalui peleburan membrana plasma, dekondensasi kromatin, dan pembentukan pronukleus jantan (Hunter, 1981).

Oosit mengalami mitosis, setelah terjadi fertilisasi. Sampai tahap 16 sel dapat dihitung di bawah mikroskop. Embrio diberi nama sesuai dengan jumlah sel, yaitu 1, 2, 4, dan 8 sel embrio. Embrio 16 sel disebut morula, karena masa sel menyerupai sebuah mulberry. Perkembangan selanjutnya, morula menjadi kompak dan bentuk rongga blastosis, dan embrio disebut blastosis embrio (Tanaka, 2001), pada masing-masing pembelahan sel menjadi lebih kecil (Bearden dan Fuquay, 1997).

Penelitian ini bertujuan untuk mengetahui pengaruh penambahan chorionic gonadotrophin pada medium maturasi terhadap kemampuan 
maturasi oosit, fertilisasi, dan pembelahan embrio pada kambing PE melalui IVF.

\section{Materi dan Metode}

Penelitian dilakukan pada bulan Juli 2008 sampai akhir Oktober 2008 di Laboratorium Fisiologi dan Reproduksi Ternak Fakultas Peternakan UGM, Yogyakarta.

\section{Materi penelitian}

Bahan-bahan yang digunakan dalam penelitian ini adalah ovarium kambing sebagai sumber oosit yang diperoleh dari rumah potong hewan $(\mathrm{RPH})$, semen beku kambing PE dari Balai Besar Inseminasi Buatan Singosari kode produksi PE Sinjhay F 002 200422, $\mathrm{NaCl}$ fisiologis (aquadest, $\mathrm{NaCl}$, penicillin, dan steptomycin), Dulbecco' phosphate bufferred saline/DPBS (Gibco, USA), Gfert $^{\mathrm{TM}}$ (Vitrolife, Kungsbacka, Sweden), G-1 ${ }^{\mathrm{TM}}$ v3 (Vitrolife, Kungsbacka, Sweden), G-2 ${ }^{\mathrm{TM}}$ v3 (Vitrolife, Kungsbacka, Sweden), sperm rinse (Vitrolife, Kungsbacka, Sweden), chorionic gonadotrophin (CG) (chorulon, Australia), mineral oil (Sigma, USA), tisu, dan alkohol $70 \%$.

Alat-alat yang digunakan adalah laminar air flow (LAF) (Envair, England), inkubator CO2 (Cole Parmer, USA), mikroskop stereo (Cole Parmer, USA), mikroskop elektrik (Nikon SE, Japan), kamera cyber-shot (Sony, Japan), timbangan analitik

(Sartorius, Jerman), oven $80^{\circ} \mathrm{C}$ (Jouan, France), syringe disposable $5 \mathrm{ml}$ dan jarum $23 \mathrm{G}$ x 11/4" $(0,65 \times 32 \mathrm{~mm})$ (Terumo, Philippines), counter dan bilik kamar hitung Neubauer, disposable tisue culture dish (TCD) (Falcon, Amerika Serikat) ukuran $35 \times 10 \mathrm{~mm}$ dan $60 \times 15 \mathrm{~mm}$, tabung microhaematocrite (Brand, Wertheim), gunting, insemination gun, gelas ukur $250 \mathrm{ml}$, tabung erlenmeyer $250 \mathrm{ml}$, kompor listrik, stirer, termos, hot plate, termometer, micropipet (L-pipette P-Boy, Japan) dan disposable tip, penggaris (ukuran $\mathrm{mm}$ ), lampu spiritus, pinset, kikir, sendok gading, kertas alumunium, ependorf, sentrifus dan tabung sentrifus, pipet pasteur, dan pipet aspirasi yang dimodifikasi.

\section{Metode penelitian}

Metode yang dilakukan dalam penelitian ini menurut Gordon (1994), yaitu koleksi oosit, maturasi oosit, persiapan sperma, persiapan sperma, fertilisasi, dan kultur embrio. Sterilisasi alat dilakukan sebelum dipergunakan untuk penelitian guna mencegah kontaminasi mikroorganisme.

Koleksi oosit. Ovarium dari kambing yang telah disembelih di rumah potong hewan (RPH) segera diambil, kemudian dicuci dengan $\mathrm{NaCl}$ fisiologis $0,9 \%$. Ovarium dimasukkan ke dalam termos berisi $\mathrm{NaCl}$ fisiologis $0,9 \%$ suhu $31-34^{\circ} \mathrm{C}$. Ovarium dibawa ke laboratorium dalam waktu tidak lebih dari 3 jam.

Folikel yang berukuran $3,1-6,0 \mathrm{~mm}$ diaspirasi menggunakan syringe $5 \mathrm{ml}$ dan jarum yang berisi DPBS. Cairan yang diperoleh dari aspirasi diletakkan pada TCD disposibel 60x15 mm, kemudian dilakukan pencarian oosit di bawah mikroskop stereo tidak lebih dari 30 menit. Oosit yang diperoleh dicuci dengan DPBS sebanyak 3 kali (hingga bersih dari debris). Oosit yang digunakan dalam penelitian ini hanya oosit kelas 1, 2, dan 3 .

Maturasi oosit. Oosit yang diperoleh dari aspirasi folikel adalah oosit yang belum matur, sehingga harus dimaturasikan. Maturasi oosit menggunakan TCD disposibel ukuran $35 \times 10 \mathrm{~mm}$. Perlakuan maturasi oosit dibagi menjadi 3 kelompok, yaitu kelompok I, medium maturasi tanpa penambahan chorionic gonadotrophin (0); kelompok II, medium maturasi dengan penambahan chorionic gonadotrophin $10 \mu \mathrm{l} / 10 \mathrm{ml}$; dan kelompok III, medium maturasi dengan penambahan chorionic gonadotrophin $20 \mu \mathrm{l} / 10 \mathrm{ml}$. Oosit yang diperoleh, diletakkan pada $50 \mu \mathrm{l}$ tetes medium maturasi, kemudian ditutup dengan mineral oil. Oosit akan dimaturasi dalam inkubator $\mathrm{CO}_{2}$ pada suhu $39^{\circ} \mathrm{C}$, kadar $\mathrm{CO}_{2}$, kelembaban $95 \%$ selama 24 jam.

Persiapan sperma. Semen beku dihangatkan kembali, kemudian semen yang dikeluarkan dari straw ditampung pada tabung sentrifus. Semen ditambahkan sperm rinse $0,5 \mathrm{ml}$ dan disentrifus pada kecepatan $485 \mathrm{G}$ selama 15 menit. Cairan bagian atas (supernatan) diambil dengan pipet pasteur secara hati-hati. Pencucian dilakukan 3 kali dengan cara yang sama. Endapan yang telah dicuci sebanyak 3 kali ditambah $0,5 \mathrm{ml} \mathrm{G}-\mathrm{Fert}^{\mathrm{TM}}$. Konsentrasi sperma yang diperoleh adalah $12,5 \times 10^{6}$ spermatozoa/ml dan motilitas lebih dari 50\%. Suspensi spermatozoa dibuat tetes spermatozoa $50 \mu \mathrm{l}$ dalam disposibel TCD ukuran $35 \times 10 \mathrm{~mm}$, kemudian ditutupi dengan mineral oil. Tetes spermatozoa dimasukkan inkubator $\mathrm{CO}_{2}$ suhu $39^{\circ} \mathrm{C}$, kadar $\mathrm{CO}_{2} 5 \%$, kelembaban $95 \%$ selama 2,5 jam. Catatan, supaya kapasitasi sperma dan maturasi oosit bersamaan, persiapan sperma dilakukan 3,5 jam sebelum waktu maturasi oosit.

Fertilisasi. Oosit yang sudah dimaturasikan secara in vitro dicuci dengan DPBS sebanyak 3 kali, kemudian oosit dimasukkan dalam tetes suspensi spermatozoa kapasitasi. Proses fertilisasi dilakukan dalam inkubator $\mathrm{CO}_{2}$ pada suhu $39^{\circ} \mathrm{C}$, kadar $5 \%$, kelembaban selama 5 jam (Gordon, 1994).

Kultur embrio. Oosit yang telah difertilisasi in vitro dicuci dengan DPBS sebanyak 3 kali. Oosit dipindahkan ke dalam $50 \mu 1$ tetes $\mathrm{G}-1^{\mathrm{TM}}$ pada disposibel TCD ukuran $35 \times 10 \mathrm{~mm}$, kemudian dimasukkan dalam inkubator $\mathrm{CO}_{2}$ pada suhu $39^{\circ} \mathrm{C}$, kadar 5\%, kelembaban 95\%. Perkembangan embrio 
diamati setiap 24 jam. Media diganti setiap 48 jam. Media $\mathrm{G}-2^{\mathrm{TM}}$ digunakan hari kedua setelah kultur (Gordon, 1994).

Analisis data. Variabel yang diamati meliputi angka oosit yang matur (maturation rate), angka fertilisasi (fertilization rate), dan angka pembelahan (cleavage rate). Data dianalisis dengan ChiSquare, menggunakan program SPSS 15,0 (Astuti, 2007).

\section{Hasil dan Pembahasan}

\section{Maturasi oosit in vitro}

Hasil maturasi oosit kambing PE secara in vitro dengan penambahan chorionic gonadotrophin pada medium maturasi tidak berbeda nyata yaitu kelompok I $\left(\mathrm{CG}_{0}\right)$ sebesar 78,0\%, kelompok II $\left(\mathrm{CG}_{10}\right)$ sebesar $72,8 \%$, dan kelompok III $\left(\mathrm{CG}_{20}\right)$ sebesar $75,0 \%$. Persentase oosit yang matur dapat dilihat pada Tabel 1.

Hal ini disebabkan kualitas oosit yang digunakan penelitian hampir seragam, yaitu kualitas 1, 2 , dan 3, dan berasal dari folikel yang berukuran 3,1-6,0 $\mathrm{mm}$, sehingga pengaruh penambahan chorionic gonadotrophin pada medium maturasi tidak terlihat. Kualitas oosit menjadi suatu yang penting untuk perkembangan embrio sebelum dan sesudah aktivasi gen, mengingat fakta bahwa aktivasi gen embrio yang tepat adalah sebuah kunci yang fundamental untuk perkembangan embrio (Schultz, 2002; Camargo et al., 2006).

Maturasi oosit pada kambing dan domba terjadi kurang lebih 24 jam dengan penambahan FSH/LH pada IVM medium (serum disuplementasi dengan M-199) (Younis et al., cit. Gordon 1994), oosit yang berasal dari folikel yang berdiameter 2-6 $\mathrm{mm}$ mengalami maturasi meiosis (86\%) dan 1-2 mm (24\%) (De Smedt et al., 1992).

Penambahan chorionic gonadotrophin dengan dosis $10 \mu \mathrm{l} / 10 \mathrm{ml}\left(\mathrm{CG}_{10}\right)$ dan $20 \mu \mathrm{l} / 10 \mathrm{ml}$ $\left(\mathrm{CG}_{20}\right)$ tidak efektif untuk meningkatkan maturasi oosit. Pada penelitian Wang et al. (1998), penambahan FSH dan LH pada medium maturasi dapat meningkatkan maturasi oosit dibanding dengan hanya penambahan hCG. Choi et al. (2001), penambahan FSH dan LH pada media maturasi dapat meningkatkan ekspansi sel kumulus. Dosis maksimal penambahan hormon pada media maturasi adalah $1 \mu \mathrm{g} / \mathrm{ml} \mathrm{FSH} \mathrm{dan} 1 \mu \mathrm{g} / \mathrm{ml} \mathrm{LH}$. Kombinasi M-199 (media kultur) dengan FSH, LH, dan $\mathrm{E}_{2}$ suplemen $10 \%$ fetal calf serum (FCS) sangat efektif untuk maturasi in vitro (Pawshe et al., 1996). Ciri-ciri oosit matur paling mudah diamati adalah adanya ekspansi sel-sel kumulus yang mengelilingi oosit dan zona pelusida terlihat jelas. Tidak semua PB I terlihat saat IVM selama 24 jam, hal ini dikarenakan perkembangan fase maturasi setiap oosit berbeda-beda dan tidak dilakukan pengecatan. Menurut Gordon (1994), evaluasi proses maturasi yaitu tingkat maturasi nukleus, ekspansi sel kumulus, dan penilaian morfologi dan metode pengecatan. Oosit yang telah dimaturasi secara in vitro, sel-sel yang mengelilingi oosit menyebar dan terjadi perubahan pada ruang perivitelin yaitu adanya PB I dan pembentukan metafase II (M II) gelendong tangential pada permukaan vitelin. Sesuai dengan Linn et al., 2003 cit. Widayati, 2008, maturasi yang baik adalah ekspansi kumulus, korona radiata terlihat bersinar, zona pelusida jelas, ooplasma bersih, kumpulan membran sel granulosa ekspansi dengan bagus. Menurut Veeck, 1988 cit. Balaban dan Urman (2006), sebuah kualitas yang baik dari oosit M II adalah oosit bersih, granular sitoplasma sedang, ruang perivitelin sempit, dan warna zona pelusida yang jelas.

Maturasi oosit terdiri dari dua proses yang berbeda yaitu maturasi nukleus dan sitoplasma Keduanya akan berkoordinasi dengan baik untuk menjamin kualitas oosit. Bahkan oosit yang sudah mengalami maturasi nukleus, oosit masih terdapat kemungkinan terjadi defisiensi maturasi sitoplasma. Semua proses itu menyiapkan oosit untuk aktivasi, kemampuan fertilisasi, dan kemampuan untuk berkembang lebih lanjut (Ebner, 2006).

Pengamatan tentang variasi morfologi oosit sering diamati pada sitoplasma dan perubahan di-

Tabel 1. Persentase oosit yang matur dari kelompok perlakuan dengan level chorionic gonadotrophin yang berbeda pada medium maturasi setelah maturasi in vitro (mature oocyte (\%) in treatment groups of addition of chorionic gonadotrophin in maturation medium after in vitro maturation)

\begin{tabular}{cccc}
\hline \hline $\begin{array}{c}\text { Kelompok } \\
\text { (group) }\end{array}$ & $\begin{array}{c}\text { Jumlah oosit yang } \\
\text { diamati (oocyte observed })\end{array}$ & $\begin{array}{c}\text { Jumlah oosit yang tidak matur } \\
\text { (immature oocyte) }\end{array}$ & $\begin{array}{c}\text { Jumlah oosit yang matur (mature } \\
\text { oocyte) }\end{array}$ \\
\hline I $\left(\mathrm{CG}_{0}\right)$ & 82 & $18(22,00 \%)$ & $64(78,00 \%)$ \\
II $\left(\mathrm{CG}_{10}\right)$ & 81 & $22(27,20 \%)$ & $59(72,80 \%)$ \\
III $\left(\mathrm{CG}_{20}\right)$ & 84 & $21(25,00 \%)$ & $63(75,00 \%)$ \\
\hline
\end{tabular}

$\mathrm{CG}_{0}$ : chorionic gonadotrophin 0

$\mathrm{CG}_{10}$ : chorionic gonadotrophin $10 \mu \mathrm{l} / 10 \mathrm{ml}$

$\mathrm{CG}_{20}$ : chorionic gonadotrophin $20 \mu \mathrm{l} / 10 \mathrm{ml}$ 
dalamnya, seperti: warna, granular dan homogenitas sitoplasma, dan bentuk sitoplasma. Hal lain yang dapat diamati adalah variasi di luar sitoplasma: ruang perivitelin yang normal, warna zona pelusida, dan bentuk oosit (Blerkom, 1990). Perkembangan embrio dipengaruhi oleh morfolgi sitoplasma dan di luar sitoplasma oosit, tetapi pengaruh morfologi oosit terhadap perkembangan embrio masih diperdebatkan dan belum ada literatur yang jelas (Balaban dan Urman, 2006).

Kumulus sel berperan penting untuk maturasi oosit dengan cara menjaga oosit menahan meiosis, mempengaruhi kelanjutan meiosis dan mempengaruhi maturasi sitoplasmik. Fungsi tersebut mempunyai hubungan dengan gap junction dan kemampuan metabolisme. Kontak fisik antara oosit dan sel kumulus untuk transfer nutrien dan faktor penting untuk perkembangan oosit. Secara sederhana peningkatan angka maturasi pada oosit kokultur, karena produksi faktor parakrin dengan penambahan sel kumulus, yang dimungkinkan transfer sebagian denud oosit melalui gap junction. Hal ini sebagai bukti sel kumulus tidak hanya meningkatkan IVM tetapi juga menyelamatkan oosit dari degerasi (Hassan dan Kazim, 2004).

\section{Fertilisasi in vitro}

Hasil fertilisasi oosit kambing PE secara in vitro dengan penambahan chorionic gonadotrophin pada medium maturasi tidak berbeda nyata, yaitu sebesar kelompok I $\left(\mathrm{CG}_{0}\right)$ 76,6\%, kelompok II $\left(\mathrm{CG}_{10}\right)$ sebesar $74,6 \%$, dan kelompok III $\left(\mathrm{CG}_{20}\right)$ sebesar $77,8 \%$. Persentase oosit yang terfertilisasi dapat dilihat pada Tabel 2.

Hal ini disebabkan kualitas oosit yang digunakan hampir seragam. Angka fertilisasi dan kualitas embrio berhubungan dengan kualitas oosit (Alikani et al., 1995; Sutter et al., 1996 cit. Ebner, 2006).

Penambahan chorionic gonadotrophin tidak efektif untuk meningkatkan angka fertilisasi, karena fertilisasi dapat terjadi tanpa atau dengan penam- bahan chorionic gonadotrophin. Saat maturasi terjadi ekspansi sel-sel kumulus yang dapat membantu spermatozoa menembus sel-sel kumulus. Menurut Mogas et al. (1997), perlakuan hormonal tidak meningkatkan IVM, IVF atau perkembangan embrio, tetapi mungkin meningkatkan kualitas oosit per ovarium, karena kualitas oosit yang baik menyiapkan untuk aktivasi, kemampuan fertilisasi, dan kemampuan untuk berkembang lebih lanjut (Ebner, 2006). Berbeda dengan penelitian Pawshe et al. (1996), M-199 dengan FSH, LH, dan $\mathrm{E}_{2}$ suplemen $10 \%$ fetal calf serum (FCS) pada IVM tidak hanya berpengaruh pada metafase II, tetapi juga mempunyai pengaruh besar pada IVF dan perkembangan embrio.

Menurut Hunter (1981) bahwa sumber, kondisi, motilitas, dan konsentrasi suspensi spermatozoa dapat mempengaruhi IVF. Dalam penelitian ini, spermatozoa yang digunakan berkualitas baik dan dapat hidup dalam medium kurang lebih selama 48 jam, sehingga tidak mempengaruhi fertilisasi. Masa hidup sperma kambing/domba dalam alat reproduksi betina adalah 30-48 jam, sedangkan masa hidup oosit adalah 16-24 jam (Hafez dan Hafez, 2000).

Penambahan chorionic gonadotrophin pada medium maturasi tidak berbeda nyata terhadap angka fertilisasi karena medium yang dipakai adalah $\mathrm{G}-$ fert $^{\mathrm{TM}}$ (Vitrolife, Kungsbacka, Sweden). G-fert ${ }^{\mathrm{TM}}$ adalah medium basal yang mengandung karbohidrat dan asam amino yang diperlukan untuk membantu terjadinya fertilisasi. Sehingga, penambahan chorionic gonadotrophin pada medium maturasi tidak meningkatkan angka fertilisasi. Unsur pokok pada kultur medium adalah mencukupi kebutuhan oosit. Pada medium maturasi harus tersedia sumber energi, nutrien atau garam. Glukosa adalah energi utama yang dikonsumsi oleh sel. Konsentrasi glukosa yang rendah digunakan untuk medium kultur embrio. Beberapa asam amino juga bisa digunakan sebagai energi untuk embrio, seperti yang terdapat pada sekresi alat reproduksi betina. Asam

Tabel 2. Persentase oosit yang terfertilisasi dari kelompok perlakuan penambahan chorionic gonadotrophin pada medium maturasi setelah difertilisasi in vitro (percentage of fertilized oocyte in treatment groups of addition of chorionic gonadotrophin into maturation medium after in vitro fertilization)

\begin{tabular}{cccc}
\hline \hline $\begin{array}{c}\text { Kelompok } \\
\text { (group) }\end{array}$ & $\begin{array}{c}\text { Jumlah oosit yang } \\
\text { matur (mature oocyte) }\end{array}$ & $\begin{array}{c}\text { Jumlah oosit yang tidak } \\
\text { terfertilisasi (unfertilized oocyte) }\end{array}$ & $\begin{array}{c}\text { Jumlah oosit yang terfertilisasi } \\
\text { (fertilized oocyte) }\end{array}$ \\
\hline I $\left(\mathrm{CG}_{0}\right)$ & 64 & $15(23,40 \%)$ & $49(76,60 \%)$ \\
II $\left(\mathrm{CG}_{10}\right)$ & 59 & $15(25,40 \%)$ & $44(74,60 \%)$ \\
III $\left(\mathrm{CG}_{20}\right)$ & 63 & $14(22,20 \%)$ & $49(77,80 \%)$ \\
\hline
\end{tabular}

$\mathrm{CG}_{0}$ : chorionic gonadotrophin 0

$\mathrm{CG}_{10}$ : chorionic gonadotrophin $10 \mu \mathrm{l} / 10 \mathrm{ml}$

$\mathrm{CG}_{20}$ : chorionic gonadotrophin $20 \mu \mathrm{l} / 10 \mathrm{ml}$ 
amino digunakan untuk meningkatkan perkembangan embrio, mengurangi stres, dan fragmentasi sel pada medium kultur. Pelepasan metabolisme asam amino bisa membahayakan embrio, sehingga medium harus diganti dua atau tiga hari sekali (Gordon, 1994).

\section{Pembelahan in vitro}

Hasil pembelahan oosit kambing PE secara in vitro dengan penambahan chorionic gonadotrophin pada medium maturasi berbeda nyata $(\mathrm{P} \leq 0,05)$, yaitu kelompok I $\left(\mathrm{CG}_{0}\right)$ sebesar 40,8\%, kelompok II $\left(\mathrm{CG}_{10}\right)$, sebesar $11,4 \%$, dan kelompok III $\left(\mathrm{CG}_{20}\right)$ sebesar $12,2 \%$. Persentase oosit yang membelah dapat dilihat pada Tabel 3 .

Penambahan chorionic gonadotrophin pada medium maturasi mempunyai persentase pembelahan lebih rendah daripada yang tidak diberi penambahan. Hal ini dikarenakan oosit yang sudah terfertilisasi belum tentu dapat berkembang lebih lanjut. Kemungkinan juga dosis yang digunakan kurang, karena hormon yang digunakan bukan hormon murni, sehingga aksinya kurang berpengaruh. Hormon murni sulit didapatkan dan sangat mahal. Menurut Choi et al. (2001), gonadotropin yang ditambahkan dalam medium maturasi sebaiknya gonadotropin murni. LH juga meningkatkan glikolisis, sehingga meningkatkan oksidasi glukosa pada sel kumulus oosit. Penelitian lain Keefer et al. (1993), konsentrasi LH yang tinggi menurunkan formasi polar bodi, awal pembelahan, dan perkembangan blastosis.

Penambahan chorionic gonadotrophin pada medium maturasi menyebabkan penurunan angka pembelahan nyata karena medium yang dipakai untuk kultur adalah $\mathrm{G}-1^{\mathrm{TM}}$ (Vitrolife, Kungsbacka, Sweden). G-1 ${ }^{\mathrm{TM}}$ adalah medium basal yang dibuat untuk membantu perkembangan dan pembelahan sel embrio sampai tahap 8 sel. $\mathrm{G}-1^{\mathrm{TM}}$ mengandung karbohidrat, asam amino, dan chelators pada saat awal embrio. Menurut Gordon (1994), pada medium kultur sel dibutuhkan kombinasi 6 komponen utama yaitu growth factor, faktor adesif (daya rekat), sedikit mineral, hormon, protein, dan vitamin. Komponen-komponen tersebut terdapat pada beberapa produk komersial yang digunakan untuk kultur sel, serta tidak ada kontaminasi mikrobia.

Pembelahan 2 sel sudah terlihat pada pengamatan 24 jam setelah inseminasi, tetapi ada pula yang baru terlihat pada pengamatan 48 jam setelah inseminasi, karena perkembangan embrio secara in vitro sangat bervariasi. Faktor yang mempengaruhi perkembangan embrio adalah kualitas embrio dan lingkungan mikro IVF (Puchner, 2006). Angka pembelahan embrio kambing in vitro tertinggi pada 48 jam setelah inseminasi (Mogas et al., 1997; Pawshe et al., 1996). Pembelahan embrio domba in vitro terlihat pada 45 jam setelah inseminasi (Wang et al., 1998). Menurut Tanaka (2001), perkembangan embrio sapi in vitro yaitu 2 sel (2 hari setelah fertilisasi), 4-8 sel (3 hari setelah fertilisasi), morula/ 16-32 sel (5 hari setelah fertilisasi), compacted morula (6 hari setelah fertilisasi), early blastocyst ( 7 hari setelah fertilisasi), expanded blastocyst ( 8 hari setelah fertilisasi), dan hatched blastocyst (9 hari setelah fertilisasi). Menurut Van Soom et al. (1992), perkembangan embrio sapi secara in vitro stadium 2 , 4, 8, dan 16 sel pada jam ke-36, 42, 60, dan 102 setelah inseminasi.

Embrio yang dihasilkan sampai pada fase pembelahan 2-4 sel jika dilihat dari morfologinya termasuk kualitas A dan B, dan menurun kualitasnya setelah fase pembelahan 8 sel. Kato dan Iritani (1993) menyatakan perkembangan embrio in vitro biasanya terhenti pada fase $8-16$ sel. Hal ini memberi petunjuk tentang adanya transisi kontrol dari induk ke embrio. Van Soom et al. (1992), perkembangan embrio 8-16 sel merupakan masa yang sangat sensitif terhadap lingkungan.

Evaluasi meliputi: 1) Kepadatan dari sel, embrio normal lebih padat dibanding kehilangan massa sel; 2) Regularitas bentuk, bentuk seperti bola lebih baik dibanding bentuk bulat lonjong; 3) Variasi dalam ukuran sel, ukuran blastomer yang

Tabel 3. Persentase oosit yang membelah dari kelompok perlakuan penambahan chorionic gonadotrophin pada medium maturasi setelah difertilisasi in vitro (percentage of cleaved oocyte in treatment groups of addition of chorionic gonadotrophin into maturation medium after in vitro fertilization)

\begin{tabular}{cccc}
\hline \hline $\begin{array}{c}\text { Kelompok } \\
\text { (group) }\end{array}$ & $\begin{array}{c}\text { Jumlah oosit yang terfertilisasi } \\
\text { (fertilized oocyte) }\end{array}$ & $\begin{array}{c}\text { Jumlah oosit yang tidak } \\
\text { membelah (uncleaved oocyte) }\end{array}$ & $\begin{array}{c}\text { Jumlah oosit yang } \\
\text { membelah (cleaved oocyte) }\end{array}$ \\
\hline I $\left(\mathrm{CG}_{0}\right)$ & 49 & $29(59,20 \%)$ & $20(40,80 \%)^{\mathrm{a}}$ \\
II $\left(\mathrm{CG}_{10}\right)$ & 44 & $39(88,60 \%)$ & $5(11,40 \%)^{\mathrm{b}}$ \\
III $\left(\mathrm{CG}_{20}\right)$ & 49 & $43(87,80 \%)$ & $6(12,20 \%)^{\mathrm{b}}$ \\
\hline
\end{tabular}

$\overline{\mathrm{a}, \mathrm{b}}$ Superskrip yang berbeda pada kolom yang sama menunjukkan perbedaan yang nyata $(\mathrm{P} \leq 0,05)$ (different superscripts at the same column indicate significant differences $(P \leq 0.05))$.

$\mathrm{CG}_{0}$ : chorionic gonadotrophin 0

$\mathrm{CG}_{10}$ : chorionic gonadotrophin $10 \mu \mathrm{l} / 10 \mathrm{ml}$

$\mathrm{CG}_{20}$ : chorionic gonadotrophin $20 \mu \mathrm{l} / 10 \mathrm{ml}$ 
sama; 4) Warna dan tekstur sitoplasma, harus bercahaya dan tidak terlalu gelap; 5) Adanya gelembung, pada sitoplasma seharusnya tidak mengandung gelembung bahkan yang berukuran kecil; 6) Adanya sel yang tertekan, seharusnya tidak mengandung sel yang tertekan; 7) Ukuran embrio normal; 8) Regularitas zona pellucida; 9) Adanya reruntuhan dari sel, seharusnya tidak ada sedikitpun fragmentasi (reruntuhan) sel dari sekeliling blastomer; dan 10) Perkembangan sel yang sesuai dengan umur embrio (Bearden dan Fuquay, 1997).

Klasifikasi kualitas embrio berdasarkan morfologis adalah: Kualitas embrio A (excelent), stadium embrio sesuai dengan yang diinginkan (morula, blastosis dini atau blastosis), tidak cacat, bentuk bundar spherical, ikatan blastomer erat dan kompak, bentuk simetris, dan warna agak cerah; kualitas embrio B (good), stadium perkembangan 16-32 sel, tampak sedikit cacat seperti keluarnya salah satu blastomer dari ikatan, dan bentuk asimetris; kualitas embrio C (fair), stadium perkembangan agak terlambat satu sampai dua hari dari stadium yang diinginkan (8-16 sel), cacat, beberapa blastomer keluar, dan ukuran blastomer tidak sama besar atau asimetris; kualitas embrio D (poor) dan E (very poor) tidak layak ditransfer, embrio mengalami hambatan perkembangan parah (2-8 sel), embrio mengalami degenerasi seluler, ikatan-ikatan blastomer longgar sampai lepas atau ova yang tidak terbuahi (unfertilized ova). Embrio yang kualitas A dan B yang dipilih untuk transfer embrio (D’Alessandro dan Giovanni, 2003).

Keberhasilan perkembangan embrio in vitro lebih rendah daripada in vivo, karena pada in vivo sel-sel oviduk mensintesis dan mensekresikan komponen-komponen yang diperlukan untuk perkembangan embrio tahap awal seperti protein dan faktor-faktor pertumbuhan. Protein tersebut akan dibebaskan pada saat embrio melewati oviduk, kemudian akan berikatan dengan zona pelusida dan masuk ke dalam sitoplasma embrio. Protein dan messenger ribonucleic acid (mRNA) yang terdapat pada embrio sangat penting untuk proses transkripsi yang terjadi pada stadium awal perkembangan embrio. Apabila terjadi kegagalan proses transkripsi, maka pembelahan embrio akan terhenti dan terjadi blokade (Gordon, 1994).

\section{Kesimpulan}

Penambahan chorionic gonadotrophin dalam medium maturasi tidak meningkatkan persentase maturasi, fertilisasi, dan pembelahan embrio kambing PE in vitro. Perlu dilakukan penelitian lebih lanjut dengan medium dan komponen yang berbeda dan atau dilakukan pada ternak yang lain.

\section{Daftar Pustaka}

Astuti, M. 2007. Pengantar Ilmu Statistik untuk Peternakan dan Kesehatan Hewan. Binasti Publisher. Bogor.

Balaban, B. and B. Urman. 2006. Effect of oocyte morphology on embryo development and implantation. Reproductive BioMedicine Online, 12(1):59-66.

Bearden, H.J. and J.W. Fuquay. 1997. Applied Animal Reproduction. Fourth Edition. Prentice Hall, New York. pp. 77.

Blerkom, U.J., H. Bell, and D. Weipz. 1990. Cellular and developmental biological aspects of bovine meiotic maturation, fertilization, and preimplantation embryogenesis in vitro. Journal of Electron Microscopy Technique 16 (4):289-323.

Boediono, A.T., T. Suzuki, L.Y. Li, and R.A. Godke. 1999. Offspring born from chimeras reconstructed from parthenogenetic and in vitro fertilized bovine embryos. Molecular reproduction and development (53):159-170.

Camargo, L.S.A, J.H.M. Viana, W.F. Sá, A.M. Ferreira, A.A. Ramos, and V.R. Vale Filho. 2006. Factor influencing in vitro embryo production. Anim. Reprod. 3(1):19-28.

Choi, Y.H., E.M. Carnevale, G.E. Seidel, and Jr., E.L. Squires. 2001. Effect of gonadotropins on bovine oocytes matured in TCM-199. Theriogenology 56:661-670.

D'Alessandro, G.A. and M. Giovanni. 2003. Use of purified FSH and LH for embryo production cryopreservation by conventional freezing or vitrification and transfer of embryos in dairy ewes. Italian Jurnal Animal Science 2:132140.

De Smedt, V., N. Crozet, M. Ahmed-Ali, A. Martino, and Y. Cognie. 1992. In vitro maturation and fertilization of goat oocyte. Theriogenology 37:1049-1060.

Djojosoebagio, A. 1990. Fisiologi Kelenjar Endokrin. Volume I. Departemen Pendidikan dan Kebudayaan. Direktorat Jendral Pendidikan Tinggi. Pusat antar Universitas Ilmu Hayat. Institut Pertanian Bogor. pp. 63.

Ebner, T., M. Mozer, and G. Tews. 2006. Is oocyte morphology prognostic of embryo developmental potential after ICSI. Reproductive BioMedicine Online 12(1):53-58.

Gordon, I. 1994. Laboratory Production of Cattle Embrios. CAB International. UK. pp. 30-142.

Hafez, E.S.E. and B. Hafez. 2000. Microanipulation of gametes and embryos: In Vitro Fertilization and Embryo Transfer (IVF/ET) In Reproduction in Farm Animals, Seventh 
Edition. Lea and Febiger, Philadelphia. pp. 443-465.

Hassan, M.W. and R.C. Kazim. 2004. Thickness of cumulus cell layer is a significant factor in meiotic competence of buffalo oocyte. J. Vet. Sci. 5(3):247-251.

Hunter, R.H.F. 1981. Physiology and Technology of Reproduction in Female Domestic Animal. Academic Press Limited. University of Edinburg. Terjemahan D.K. Harya Putra. 1995. Fisiologi dan Teknologi Reproduksi Hewan Betina Domestik. Penerbit Institut Teknologi Bandung, Bandung. pp. 268-285.

Kato and A. Iritani. 1993. In vitro fertilization in cattle. Mol. Reprod. and Dev. 36:229-231.

Keefer, C.L, S.L. Stice, and J. Dobrinsky. 1993. Effect of follicle-stimulating hormone and luteinizing hormone during bovine in vitro maturation on development following in vitro fertilization and nuclear transfer. Mol. Reprod. and Dev. 36:336-340.

Mogas, T., M.J. Palomo, M.D. Izquierdo, and M.T. Paramio. 1997. Developmental capacity of in vitro matured and fertilized oocytes from prepubertal and adult goats. Theriogenology 47:1189-1203.

Pawshe, C.H., A. Palanisamy, M. Taneja, S.K. Jain, and S.M. Totey. 1996. Comparison of various maturation treatments on in vitro maturation of goat oocyte and their early embryonic development and cell numbers. Theriogenology 46:971-982.

Puchner, A.M. 2006. Novel follicular fluid factors influencing oocyte developmental potential in IVF: a review. Reproductive BioMedicine Online 12(1):95-101.

Putro, P.P. 1993. Petunjuk Laboratorium Fertilisasi In Vitro. Pusat Antar Universitas Bioteknologi UGM. Yogyakarta. pp.10-19.
Schultz, R.M. 2002. The molecular foundation of the maternal to zygotic transition in the preimplantation embryo. Human Reproduction Update 8:323-331.

Situmorang, P dan E. Triwulaningsih. 2004. Aplikasi dan inovasi teknologi transfer embrio (TE) untuk pengembangan sapi potong. Lokakarya Nasional Sapi Potong. pp. 95-105.

Tanaka, H. 2001. Reproductive Biology and Biotechnology. Japan International Cooperation Agency. Indonesia. pp. 1-12.

Van Soom, A., V. Van Vlanenderen, A.R. Mahmoudzadeh, H. Deluyker, and A. De Kruif. 1992. Compaction rate of in vitro fertilized bovine embryos related to the interval from insemination to first cleavage. Theriogenology 38:905-919.

Wang, S., Y. Liu, G.R. Holyoak. R.C. Evans, and T.D. Bunch. 1998. A protocol for in vitro maturation and fertilization of sheep oocytes. Small Ruminant Research 29:83-88.

Widayati, D.T. 2008. Effect of oocyte morphology on embryo development and implantation. Materi Kuliah Program Konsultan Fertilitas dan Endokrinologi Reproduksi (Unpublished), bagian Obsgin. Fakultas Kedokteran UGM.

Williams, R.H. 1974. Textbook of Endocrinology. Asian Edition. Fifth Edition. JMC Press Incorporated. Quezon City, Philippines. pp.42.

Zuelke, K.A. and B.G. Brackett. 1992. Effects of luteinizing hormone on glucose metabolism in cumulus enclosed bovine oocyte mature in vitro. Endocrinology 131(6):2690-2697.

Zuelke, K.A. and B.G. Brackett. 1993. Increased glutamine metabolism in bovine cumulus cell enclosed and denude oocytes after in vitro maturation with luteinizing hormone. Biology of Reproduction 4:815-820. 